\title{
Anti-lipid droplets accumulation effect of Annona montana (mountain soursop) leaves extract on differentiation of preadipocytes
}

\author{
Ivy LEUNG ${ }^{1}$; Maria-Luisa VEISAGA ${ }^{2}$; MARGarita ESPINAL ${ }^{1}$; Wei ZHANG ${ }^{1}$; Robert BARNUM ${ }^{1}$; \\ Manuel Alejandro BARBIERI ${ }^{1,2,3,4, *}$ \\ ${ }^{1}$ Department of Biological Sciences, Florida International University, Miami, 33199, USA \\ 2 Biomolecular Sciences Institute, Florida International University, Miami, 33199, USA \\ ${ }^{3}$ Fairchild Tropical Botanic Garden, Coral Gables, 33156, USA \\ ${ }^{4}$ International Center of Tropical Botany, Florida International University, Miami, 33199, USA
}

Key words: Annona montana extracts, Phytochemical analysis, Adipogenesis, Lipid droplets, Adipogenic-specific markers

\begin{abstract}
The Annona genus is a member of Annonaceae, one of the largest families of plants across tropical and subtropical regions. This family has been used in several ethnomedicinal practices to treat a multitude of human diseases. However, the molecular mechanism underlying its effect on the lipid droplet formation and on the expression of adipogenic markers of this plant remain to be investigated. In this study, we examined whether the extracts from the aerial part of Annona montana affect in vitro differentiation of preadipocytes. For our investigations, both mouse embryo fibroblast 3T3-L1 and normal human primary subcutaneous preadipocytes were incubated with Annona montana extracts (-and its subfractions-) and then analyzed on preadipocyte differentiation, lipid content, lipid droplet size and number, the expression of adipogenic-specific transcriptional factors, as well as cell survival. From our examinations, we found the Annona montana ethyl acetate extract to exhibit a potent inhibitory effect on adipogenesis, without affecting cell survival, in a dose-dependent manner. Such inhibitory effects included a significant decrease in the accumulation of lipid content by both a dramatic reduction of size and number of lipid droplets. This extract strongly attenuated the expression of PPAR $\gamma$ and HMGB2. It also inhibited the expression of CEBPa, FAS, and Akt without influencing Erk1/2 activities. Our findings suggest that specifically, the Annona montana ethyl acetate extract has a prominent inhibitory effect in cellular pathways of adipocyte differentiation by modulating specific gene expression, which is known to perform a pivotal role during adipogenesis.
\end{abstract}

\section{Introduction}

The Annonaceae is a large family of plants containing approximately 130 genera and more than 2100 species. The fruits, seeds, leaves, and flowers of many of the Annonaceae plants are used in traditional medicines for the treatment of a variety of diseases. The Annona species are a potent source of a wide variety of secondary metabolites (e.g., acetogenins) belonging to several categories (Agostini et al., 1995; CoriaTéllez et al., 2018; Rauter et al., 2002; Moghadamtousi et al., 2015; Mootoo et al., 2000; Tundis et al., 2017; Wang et al., 2002; Wu et al., 1995).

Annona (A.) montana, the mountain soursop, is an edible, fibrous fruit in the Annonaceae family and is native to Central America, the Amazon, and Caribbean Islands. A. montana is

*Address correspondence to: Manuel Alejandro Barbieri, barbieri@fiu.edu Received: 29 August 2020; Accepted: 16 August 2021 also popularly known as guanabana or false graviola due to its similarity with graviola (A. muricata); however, $A$. montana exhibits glossy leaves and a more conspicuous spreading crown (Chatrou et al., 2012). In addition to $A$. montana, other species of the genus (e.g., A. muricata, A. crassiflora, A. diversifolia, and A. squamosa) are used in some countries as folk medicine based on their biological properties (e.g., anticancer, antiparasitic, antispasmodic, antidiarrheal, antiulcer, sedative, hypotensive, anthelmintic and antioxidant) (Adewole and Ojewole, 2008; Bailon-Moscosoa et al., 2016; Carballo et al., 2010; Degli Esposti et al., 1994; Dragano et al., 2010; Ponrasu and Suguna, 2012). Though, their efficacy as a medicine to treat disease, especially chronic illnesses, has yet to be validated scientifically.

One of the chronic, degenerative diseases is obesity, which has become one of the most prevalent metabolic diseases throughout the world. Obesity and its association with other illnesses and conditions have thus become 
significant burdens to global health pursuits in combating chronic disease and disability. Obesity, which stems from the excess storage of adipose tissue, is primarily caused by a significant increase in the amount of adipocytes due to the proliferation and differentiation of preadipocytes into mature adipocytes (Collaborators et al., 2017).

Several animal models, as well as in vitro systems, have been used extensively in diabetes research. Both mouse (3T3-L1) and human preadipocytes have been useful in vitro models for studying obesity, due to the observable accumulation of triglycerides upon differentiating in culture (Rosen and Spiegelman, 2000). Adipocyte differentiation is induced by either or both the expression and phosphorylation or either of specific genes, such as PPAR $\gamma$, C-EBPa, AMPK, HMGB2, and Akt1 (Bost et al., 2005; Kemp et al., 2003; Lee et al., 2018; Rosen and Spiegelman, 2000; Spiegelman et al., 1993). Thus, several crude aqueous and organic solvents of plant extracts, as well as other pure active compounds that specifically target and inhibit adipogenesis, have been considered potentially promising treatments for obesity (Roberts et al., 2010). While many plants have been utilized to reduce the risk factors of developing these chronic, degenerative illnesses (Abrams et al., 2011; de Souza Mda et al., 2012; Parraga et al., 2011; Taleghani et al., 2020), there are no studies in the literature that associate the effect of extracts from A. montana aerial parts with the differentiation of preadipocyte to adipocyte.

Consequently, the purpose of this study was to examine the effects of A. montana leaves extracts on lipid droplet formation as well as the expression of several adipogenic markers for both human and mouse preadipocyte differentiation.

\section{Materials and Methods}

\section{Reagents}

Mouse embryo fibroblast 3T3-L1 (ATCC ${ }^{\circledR}$ CL173) and normal human primary subcutaneous preadipocytes $\left(\right.$ ATCC $^{\circledR}$ PCS210010) cells were purchased from American Type Culture Collection (ATCC, Manassas, VA). Dulbecco's modified Eagle's medium high glucose (DMEM), penicillin/streptomycin and Lglutamine were purchased from Mediatech, Inc. (Manassas, VA). PPAR $\gamma$ (Cat\# 2443S), C/EBPa (Cat\# 2295S), FAS (Cat\# 4233S), HMGB2 (Cat\# 14163S), AMPKa (Cat\# 5832S) and phospho(p)-AMPKa (Cat\# 50081S-Thr172), Akt1(Cat\# 75692S) and p-Akt1 (Cat\# 9018S-Ser473) antibodies were from Cell Signaling Technology (Boston, MA). GAPDH (Cat\# G9545) antibodies were from Sigma-Aldrich (St. Louis, MO). All secondary antibodies (Cat\# 305-035-045) were purchased from Jackson ImmunoResearch Laboratories (West Grove, PA). All other chemicals were obtained from Sigma-Aldrich unless otherwise stated.

\section{Preparation of the methanol extract}

Annona montana leaves were collected from the Redland region in Miami, Florida, USA in 2019. The taxonomic identity was verified by the botanist at the herbarium of the Department of Biological Sciences at Florida International University (AMICTB1314). Leaves (2.5 g for both species, fresh weight) from one individual plant were cut into small pieces and extracted with methanol [i.e., A. montana methanol extract] $(100 \mathrm{~mL})$ in a $250 \mathrm{~mL}$ round bottom flask connected to a reflux condenser heated at $65^{\circ} \mathrm{C}$ for $45 \mathrm{~min}$. The leaves were filtered, and plant material was washed twice with methanol $(25 \mathrm{~mL})$. The extract and washes were pooled. Evaporation of the methanol extract by rotavapor/desiccation yielded a residue of $540 \mathrm{mg}$ for A. montana.

\section{Fractionation of the methanol extract}

The individual plant methanol extract was partitioned among hexane, ethyl acetate and water. Briefly, leaves were extracted with methanol as indicated above. An aliquot $(300 \mathrm{mg})$ of the residue obtained by methanol extraction was partitioned between methanol and hexane. The hexane was removed from the methanolic phase, then evaporated and concentrated by rotavapor/desiccation as previously described to obtain $A$. montana extract-hexane; the residue was partitioned between water (A. montana extract-water, and $A$. montana extract-ethyl acetate, respectively). These fractions were then individually evaporated and concentrated by rotavapor/desiccation as previously described (Galvis et al., 2011). The hexane, ethyl acetate, and water extracts yielded 24, 78, and $150 \mathrm{mg}$ of residue for A. montana, representing approximately $84 \%$ of the initial methanol extract. All extracts were dissolved in dimethyl sulfoxide (DMSO) at a final concentration of $100 \mathrm{mg} / \mathrm{ml}$ plant extract.

\section{$G C$ and $G C / M S$ analyses}

GC/MS determinations were carried out in a Hewlett Packard model 6890 instrument coupled to a Q-Mass 910 quadrupole selective detector (Perkin-Elmer) at $70 \mathrm{eV}$. A fused capillary column was used (DB-5MS, $30 \mathrm{~m} \times 0.25 \mathrm{~mm}$ i.d.; film thickness $0.25 \mu \mathrm{m}$; J\&W Scientific); injection port temperature, $230^{\circ} \mathrm{C}$; splitless for $1 \mathrm{~min}$ then split ratio $1 / 10$; detector temperature, $270^{\circ} \mathrm{C}$; carrier gas, helium at $0.7 \mathrm{~mL} /$ minute; temperature program: $50-230^{\circ} \mathrm{C}$ linear increase at $3{ }^{\circ} \mathrm{C} /$ minute. Scanning speed was 2.48 scan/second with mass spectra recorded from 50 to $650 \mathrm{~m} / \mathrm{z}$. GC/FID determinations were performed on a Trace GC Ultra apparatus (Thermo Electron Corporation) equipped with an FID. The output was recorded using a ChromQuest version 4.1 data system. Analyses were performed on capillary columns DB-5MS at the conditions stated above (Adams, 2007; Araujo et al., 2007; Babushok et al., 2011).

\section{Cell culture and differentiation}

Mouse 3T3-L1 cells were routinely maintained in Dulbecco's modified Eagle's medium (DMEM) high glucose supplemented with $10 \%$ fetal bovine serum (Invitrogen, Carlsbad, CA), $1 \%$ penicillin/streptomycin and $1 \%$ L-glutamine (growth media) in a humidified atmosphere of $5 \% \mathrm{CO}_{2}$ at $37^{\circ} \mathrm{C}$ as described in the ATCC toolkit's instructions (ATCC ${ }^{\circledR}$ PCS210010 ${ }^{\mathrm{TM}}$ ). Cells were split every $72 \mathrm{~h}$ and they were used up to 10 consecutively passages. To trigger differentiation cells were exposed to induction medium (IM) (growth media supplemented with $10 \mathrm{mg} / \mathrm{mL}$ insulin, $1 \mathrm{mM}$ dexamethasone and $0.5 \mathrm{mM}$ 3-isobutyl-1methylxanthine [IBMX]) for the first two days, then fed with post-differentiation media (DMEM high glucose supplemented with $10 \mathrm{mg} / \mathrm{mL}$ insulin, 5\% fetal bovine 
serum, $1 \%$ penicillin/streptomycin and $1 \%$ L-glutamine) for the next seven days. Cells were exposed to A. montana extracts throughout the entire differentiation process, unless otherwise indicated. Human primary subcutaneous preadipocytes were routinely maintained in fibroblast basal medium supplemented with the fibroblast growth kit-low (ATCC, Manassas, VA) containing 2\% Fetal Bovine Serum, $5 \mathrm{ng} / \mathrm{mL}$ rh-FGF basic, 7.5 $\mathrm{mM}$ L-glutamine, $50 \mathrm{mg} / \mathrm{mL}$ ascorbic acid, $1 \mathrm{mg} / \mathrm{mL}$ hydrocortisone hemisuccinate, and $5 \mathrm{mg} / \mathrm{mL}$ rh-insulin as described in the ATCC's instructions. Differentiation of human primary subcutaneous preadipocytes was induced by replacing basal media with initiation media for the first three days followed by maintenance media for eleven days; both the initiation and maintenance media were prepared from the adipocyte differentiation toolkit purchased from ATCC (ATCC ${ }^{\circledR}$ PCS500050, Manassas, VA). The human preadipocytes underwent $A$. montana extracts treatment throughout the entire differentiation process. The half maximal inhibitory concentration $\left(\mathrm{IC}_{50}\right)$ is a quantitative measure that indicates how much of a particular inhibitory substance (e.g., plant extracts) is needed to inhibit, in vitro, a given biological process by $50 \%$ and it was essentially determined as described by Beck et al. (2012).

\section{Oil Red O staining, microscopy and image analysis}

On the ninth day of experimentation, the cells were fixed with $10 \%$ formalin (Thermo Fisher Scientific, Inc., Pittsburgh, PA) in phosphate-buffered saline (PBS) at $4^{\circ} \mathrm{C}$ for $1 \mathrm{~h}$. Oil Red $\mathrm{O}$ (Allied Chemical, Morristown, NJ) stock solution ( $0.6 \mathrm{~g}$ in $100 \mathrm{ml}$ of $100 \%$ isopropanol) was diluted with 0.6 parts of double-distilled water, filtered, and added to the fixed cells for $15 \mathrm{~min}$ at room temperature. Cells were then washed with double-distilled water and analyzed under a Leica DM IRB inverted microscope. Photos of lipid droplets were taken with the digital Leica DC 500 camera. To quantify the lipid content from the lipids droplets stained with diazo dye Oil Red O (ORO). Then, ORO was eluted with $100 \%$ isopropanol for $10 \mathrm{~min}$ at $37^{\circ} \mathrm{C}$, collected, and the optical density was measured at $540 \mathrm{~nm}$. For image analysis, control and treated cells were processed as described above and the stained lipid droplets were visualized by a Leica DM IRB inverted microscope, photographed and digitized with a digital Leica DC 500 software at $400 \mathrm{x}$ magnification. The number and size distribution of endosomes was analyzed by the NIH Image software, which can be accessed at the website (http://rsb.info.nih.gov/nihimage/). The total number of lipid droplets was quantified from, at least, 107 cells. The perimeters of 1484 lipid droplets from fortyfive ontrol cells and 992 lipid droplets from sixty two $40 \mathrm{mg} / \mathrm{mL}$ AMEaE-treated cells were obtained by using NIH Image software. The mean perimeter and the relative variance for the lipid droplets from control cells are 7.15 (2.27 diameter) and 0.41 , while the corresponding values for lipids droplets the $40 \mathrm{mg} / \mathrm{mL}$ AMEaE-treated cells are 1.64 (0.52 diameter) and 0.35 , respectively.

\section{Western blotting analysis}

For the preparation of cell lysates, cell monolayers were washed with ice-cold lysis buffer $(20 \mathrm{mM}$ Tris-HCl pH 7.5,
$150 \mathrm{mM} \mathrm{NaCl}, 1 \mathrm{mM} \mathrm{Na} \mathrm{N}_{2}$ EDTA, 1\% NP40 and 0.1\% $\mathrm{Na}$ Deoxycholate) containing both protease and phosphatase inhibitors. Lysates were collected by centrifugation, and protein concentrations were estimated by using the BCA protein assay (Thermo Fisher Scientific, Inc., Pittsburgh, PA) following the manufacturer's instructions. Proteins were resolved by $10 \%$ SDS-PAGE and transferred to nitrocellulose membranes using a traditional wet transfer (100 V for $60 \mathrm{~min}$ ), which were blocked in 5\% non-fat dried milk in Tris-buffered saline $(20 \mathrm{mM}$ Tris, $\mathrm{NaCl} 150 \mathrm{mM}$, $\mathrm{pH}: 8$ ) with $0.1 \%$ Tween $^{\circledR} 20$ detergent (TBS-T) buffer for 1 $\mathrm{hr}$ at room temperature, and then were incubated with primary antibodies against AMPKa (1:1000), p-AMPKa (1:1000), FAS (1:5000), Akt1 (1:2000), p-Akt1 (1:1000), HMGB2 (1:1000), PPAR $\gamma$ (1:1000), C-EBPa (1:2000), and GAPDH (1:5000, ab179467, Abcam) overnight at $4^{\circ} \mathrm{C}$ in $5 \%$ Bovine Serum Albumin (BSA)-TBS-T, followed by incubation with horseradish peroxidase (HRP)-conjugated secondary antibody $(1: 10,000)$ for $1 \mathrm{hr}$ at room temperature in BSA-TBS-T. The protein bands were visualized using ECL detection reagent (Millipore, Billerica, MA, USA). In these cases, we carried out western blotting analysis with anti-phospho(p)AMPKa (or p-AKT1) antibody as indicated above. Then, the blot was stripped and reprobed with anti-total(t)AMPKa (or t-AKT1) antibody to ensure equal amount of protein in each lane. This stripped and reprobed processing was carried out by Thermo Scientific Restore Plus Western Blot Stripping Buffer kit (Cat\# 46430) as indicated in the manual's instructions. Relative levels of AMPKa and Akt1 proteins were determined by densitometry using the ratio of $\mathrm{p}$ AMPKa to total(t)-AMPKa and p-Akt1 to t-Akt1, respectively. In this cases, Relative levels of FAS, HMGB2, PPAR $\gamma$, and C-EBPa were determined using the ratio of FAS to GAPDH, HMGB2 to GAPDH, PPAR $\gamma$ to GAPDH and $\mathrm{C}-\mathrm{EBPa}$ to GAPDH, respectively.

\section{Cell viability assay}

The cell viability of 3T3-L1 cells was also analyzed using a trypan blue assay as reported in a previous study (Abood et al., 2018) with minor modifications. 3T3-L1 cells $(1 \times$ $10^{4}$ cells $\left./ \mathrm{mL}\right)$ were incubated with $A$. montana extracts $(0-$ $40 \mathrm{mg} / \mathrm{mL}$ ) for 9 day. The trypsinized cell suspension were immediately stained with $0.4 \%$ trypan blue for $2 \mathrm{~min}$. The viable cells were counted by automated cell counter (BioRad, Hercules, CA, USA). The viability was expressed as the percentage ratio of the number of unstained cells relative to the total cells counted.

\section{Statistical Analysis}

All experiments were done in triplicates and they were repeated at least three times. Values are represented as the standard error of the mean (S.E.M.) of triplicates and the statistical significance was analyzed by one-way ANOVA followed by Tukey's post hoc test for multiple group comparisons. Two-tailed unpaired Student's to test was performed if only two conditions were compared. Results with ${ }^{*} P<0.05$ and ${ }^{*} P<0.01$ were considered as statistically significant. 


\section{Results}

\section{Annona montana leaves' extract inhibits differentiation of preadipocytes}

To examine the potential effect of $A$. montana leaves' extract on the preadipocyte differentiation, we incubated 3T3-L1 with induction media in the presence of various concentrations of A. montana leaves methanol's extract. In Fig. 1A, we show that the addition of $A$. montana methanol extract inhibited the lipid content in a dose-dependent manner with an $\mathrm{IC}_{50}$ of $84.9 \pm 7.2 \mu \mathrm{g} / \mathrm{mL}$. Furthermore, our experimental conditions demonstrate that the addition of DMSO $(<0.2 \%)$ exclusively does not affect 3T3-L1 preadipocyte differentiation (Fig. 1A).

We were further interested in examining the effect of $A$. montana methanol extract on the viability of 3T3-L1 preadipocytes. Cells were incubated with induction media in the presence of $40 \mu \mathrm{g} / \mathrm{mL}$ A. montana methanol extract throughout the entire differentiation period. Cell viability was measured using the trypan blue exclusion assay, as described in Material and Methods. In Fig. 1A, we show that cell viability was not affected as compared with control cells (Compare viability of control cells $(98 \pm 2 \%$ ) with the viability of cells treated with $40 \mu \mathrm{g} / \mathrm{mL}$ A. montana methanol (95 $\pm 5 \%)$. However, at increasing concentrations of A. montana methanol extract beyond $40 \mu \mathrm{g} / \mathrm{mL}, 3 \mathrm{~T} 3-\mathrm{L} 1$ preadipocytes detached from the plate, which was coupled with a reduction in the trypan blue exclusion assay (Fig. 1A). These results suggest that, up to a maximum concentration of $40 \mu \mathrm{g} / \mathrm{mL}, A$. montana methanol extract has a strong inhibitory activity of $3 \mathrm{~T} 3-\mathrm{L} 1$ preadipocyte differentiation without significant effect on cell viability.

Adipocyte differentiation was also monitored by the formation of intracellular lipid droplets (Rosen and Spiegelman, 2000). As aforementioned, 3T3-L1 preadipocytes were cultivated and induced to differentiate into adipocytes with induction media in the absence or presence of $40 \mu \mathrm{g} / \mathrm{mL}$ A. montana methanol extract. At the end of the differentiation process, Oil Red $\mathrm{O}$ staining showed an abundant number of lipid droplets, which suggested a significant lipid accumulation in untreated differentiated cells. Moreover, lipid droplets were not observed in untreated nondifferentiated cells. However, the formation of lipid droplets was inhibited by $40 \mu \mathrm{g} / \mathrm{mL}$ A. montana methanol extract treatment (Fig. 1B). The quantitative measurement of lipid content further supported these observations by determining the absorbance at $540 \mathrm{~nm}$.

Our data indicate that the methanol extract of $A$. montana exhibited inhibition of adipocyte differentiation with an $\mathrm{IC}_{50}$ of $84.9 \pm 7.2 \mu \mathrm{g} / \mathrm{mL}$. Thus, to gain information about the nature of the active compounds in A. montana leaves, the methanol extract, a complex mixture of compounds, was further fractionated as described in the Materials and Methods. Three fractions (named as hexane, ethyl acetate, and water fractions) were obtained. The $A$. montana ethyl acetate fraction exhibited the most potent inhibitory effect $\left(\mathrm{IC}_{50} \quad 7.2 \pm 3.1 \mu \mathrm{g} / \mathrm{mL}\right)$ on cell differentiation as compared with the A. montana hexane fraction, which showed an inhibition of the preadipocyte differentiation with $\mathrm{IC}_{50} 50.9 \pm 4.3 \mu \mathrm{g} / \mathrm{mL}$ (Figs. 2A and $2 \mathrm{~B})$. Interestingly, the aqueous fraction did not show any effect at all (Fig. 2C). As expected, these fractions did not show a significant reduction in the trypan blue exclusion assay (i.e., viability of cells treated by $A$. montana ethyl acetate fraction $82 \pm 5 \%$, by $A$. montana hexane fraction 93 $\pm 4 \%$, or by $A$. montana aqueous fraction $97 \pm 4 \%$ as compared with $92 \pm 8 \%$ control cells). These observations on the A. montana extracts' inhibitory effects on differentiation were further supported with the quantitative measurement of lipid content by determining the absorbance at $540 \mathrm{~nm}$ when cells were treated with different A. montana extracts. Additionally, A. montana ethyl acetate and hexane extracts treatment significantly inhibited adipogenic morphology, but not in the presence of $A$. montana aqueous extract (i.e., transition from a fibroblastlike shape to an increasingly round appearance with an accumulation of lipid droplets (Fig. 2D).

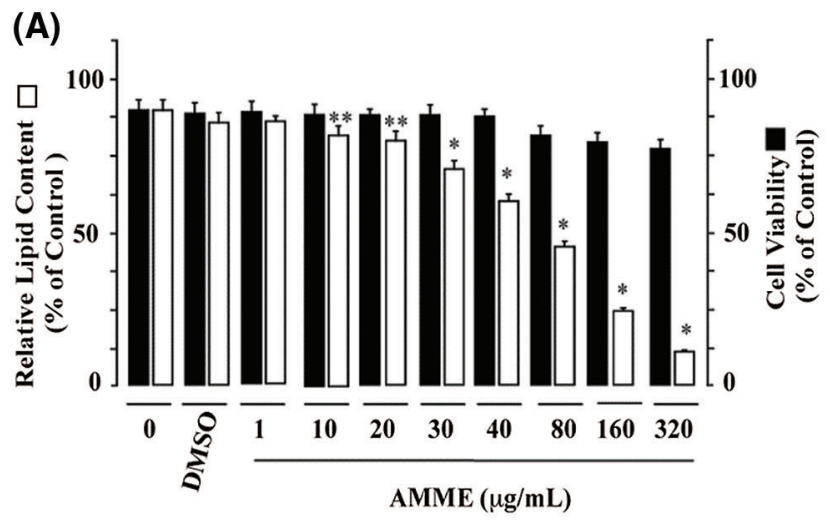

(B)

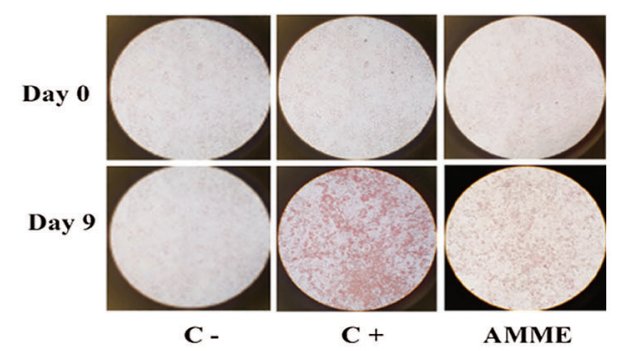

FIGURE 1. Annona montana methanol extract inhibited adipogenesis of 3T3-L1 preadipocytes without reducing cell viability.

(A) 3T3-L1 preadipocytes were differentiated into adipocytes with induction media in the absence or the presence of various amounts of $A$. montana methanol extract ( 0 to $320 \mu \mathrm{g} / \mathrm{mL}$ ) as described in Material and Methods. Results were represented as relative lipid contents for adipocyte formation (open bars) and as percentage of control for cell viability (solid bars). Data represent the mean \pm S.E.M. of three independent experiments. ${ }^{\star} P<0.05$ and ${ }^{*} P<0.01$ by one-way ANOVA test compared to DMSO-control and only induction mediatreated cells $(0 \mu \mathrm{g} / \mathrm{mL})$. (B) 3T3-L1 preadipocytes were monitored under a microscope and photographed after nine days (Day 9) from the onset of differentiation (Day 0). Vehicle only (C-), cells treated with induction media in the presence of DMSO-control (C+), or in the presence of $40 \mu \mathrm{g} / \mathrm{mL}$ A. montana methanol extract (AMME). 

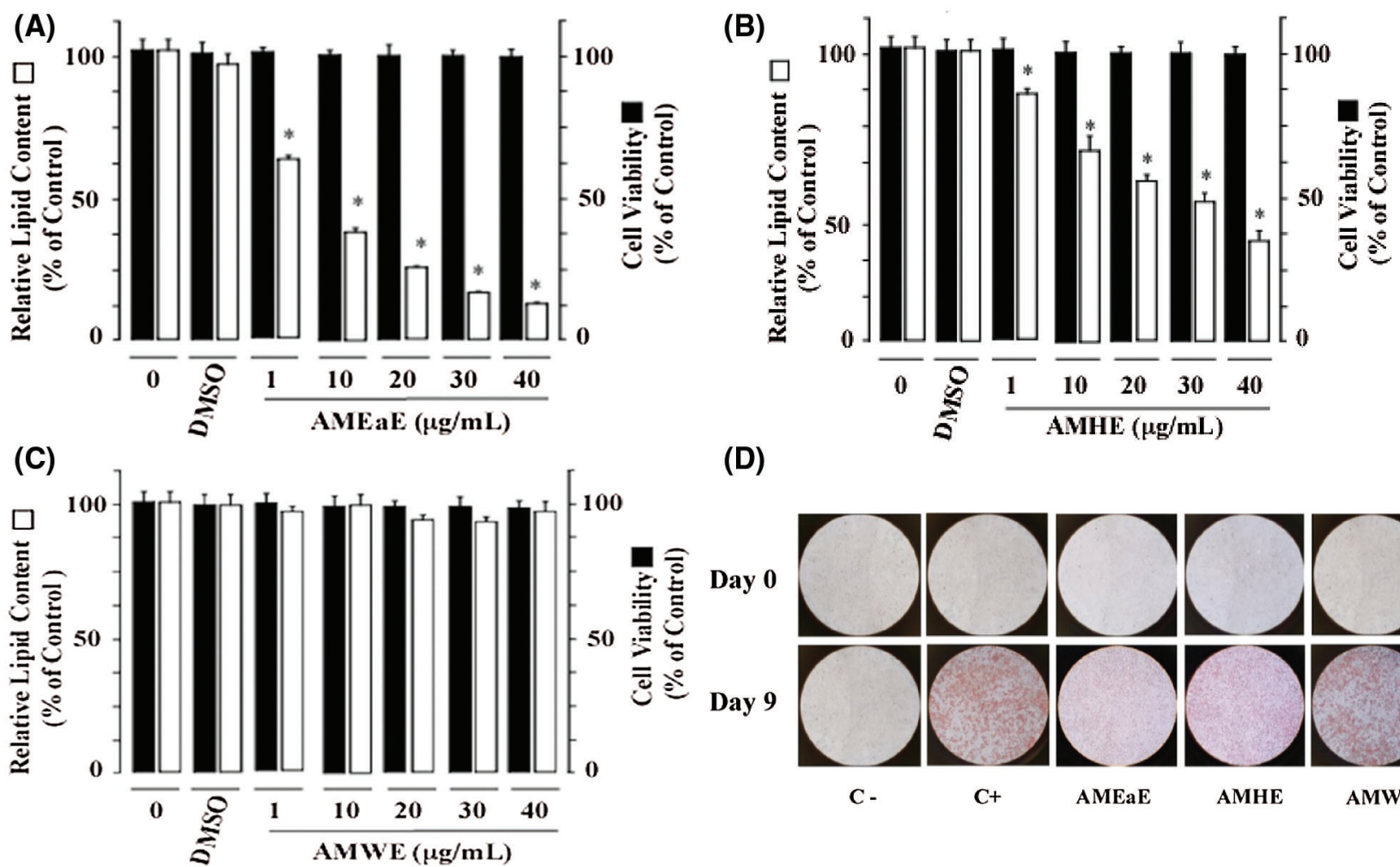

(D)

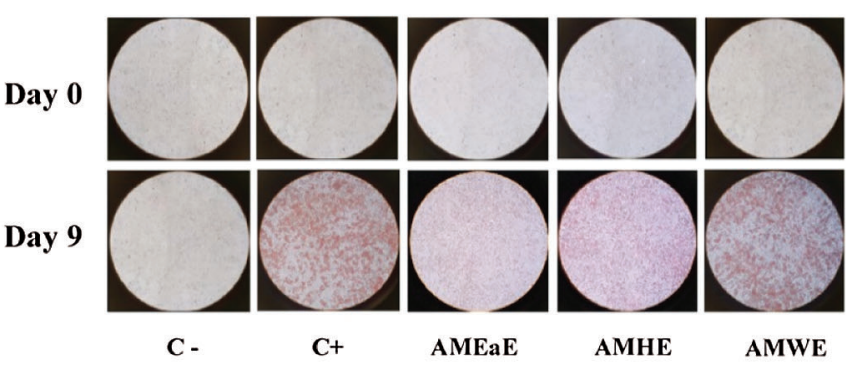

FIGURE 2. Annona montana extracts have selective inhibitory effects on the adipogenesis of 3T3-L1 preadipocytes without reducing cell viability. 3T3-L1 preadipocytes were differentiated into adipocytes with induction media in the absence or the presence of DMSO-control, or of various amounts (0 to $40 \mu \mathrm{g} / \mathrm{mL}$ ) of A. montana extracts (e.g., (A) A. montana ethyl acetate extract (AMEaE), (B) A. montana hexane extract (AMHE), and (C) A. montana water extract (AMWE) as described in Material and Methods. Results were represented as relative lipid contents. Data represent the mean \pm S.E.M. of three independent experiments. ${ }^{\star} P<0.05$ and ${ }^{* *} P<0.01$ by one-way ANOVA test compared to DMSO-control and only induction media-treated cells. (D) 3T3-L1 preadipocytes were monitored under a microscope and photographed after nine days (Day 9) from the onset of differentiation (Day 0). Vehicle only (C-), cells treated with induction media in the presence of DMSO-control (C+), or in the presence of $40 \mu \mathrm{g} / \mathrm{mL}$ A. montana extracts as indicated in the figure.

Consistent with these observations, we found that the $A$. montana ethyl acetate treatment decreased both the number and size of lipid droplets. Specifically, we observed more than $93 \%$ reduction in the number of lipid droplets and more than $87 \%$ reduction in the size of lipid droplets (Figs. 3A and 3B). Analysis of the distribution of the numbers of lipid droplet sizes showed a distinct shift of the lipid droplet size toward smaller lipid droplets following incubation with A. montana ethyl acetate extract. The mean perimeter and the relative variance for the lipid droplets from control cells are 8.54 (3.90 diameter) and 0.41 , while the corresponding values for lipids droplets of $10 \mu \mathrm{g} / \mathrm{mL} \mathrm{A}$. montana ethyl acetate extracttreated cells are 1.74 (0.81 diameter) and 0.35 , respectively (Fig. 3C). Furthermore, human primary subcutaneous preadipocytes were also subjected to A. montana ethyl acetate treatment at several concentrations (i.e., 0.25 to $40 \mu \mathrm{g} / \mathrm{mL}$ ). Observations under the microscope and Oil Red $\mathrm{O}$ analysis indicated a significant inhibition (more than 90\% inhibition) of differentiation of the preadipocytes into adipocytes with increasing concentration of $A$. montana ethyl extract without affecting cell viability (Supplemental Fig. 1A). Compared to the positive controls, A. montana ethyl acetate extract (i.e., $1 \mu \mathrm{g} / \mathrm{mL}$ ) also decreased lipid number and size in human preadipocytes (Supplemental Fig. 1B). These results suggest that, up to a maximum concentration of $10 \mu \mathrm{g} / \mathrm{mL}, A$. montana ethyl acetate extract has a strong inhibitory activity of human preadipocyte differentiation without significant effect on cell viability.

To identify the critical stage of adipogenic differentiation affected by $A$. montana ethyl acetate extract treatment, differentiating 3T3-L1 preadipocytes were treated with 10 $\mu \mathrm{g} / \mathrm{mL}$ A. montana ethyl acetate extract at various time points during adipogenic differentiation, as illustrated in Fig. 4A. Thus, we also took into consideration the possibility that the extent of inhibition is dependent on the timing of A. montana ethyl acetate extract addition. Consequently, $A$. montana ethyl acetate extract was added in discrete periods during differentiation (Fig. 4A). We observed a significant reduction in the differentiation of 3T3-L1 preadipocytes when compared with DMSO-control cells upon early $A$. montana ethyl acetate extract addition, corresponding to days 1 or 3 of treatment (e.g., treatments I and II, Fig. 4B). However, this inhibitory effect was not apparent when $A$. montana ethyl acetate was added on day 5 or day 7 of postinduction (e.g., treatments III and IV, Fig. 4B). Observations under the microscope also confirmed significant inhibition of the lipids droplets during treatment for days 1 and 3, but not for days 5 and 7, respectively (Fig. 4C). These results further demonstrate that $A$. montana ethyl acetate may show a selective and early adipocyte gene expression during in vitro differentiation. Taken together, these results suggest that A. montana ethyl acetate extract could inhibit 
(A)

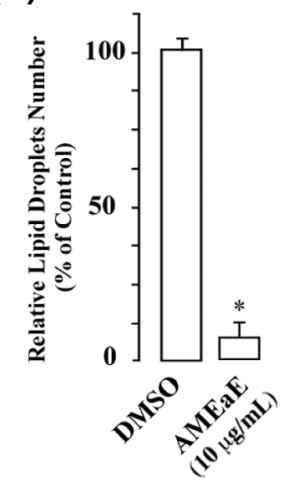

(B)

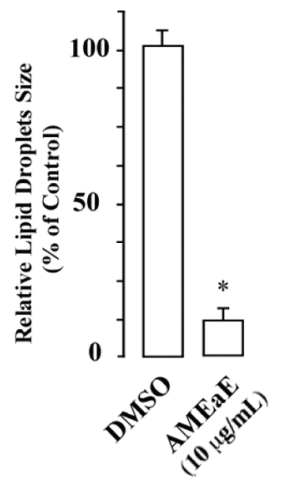

(C)

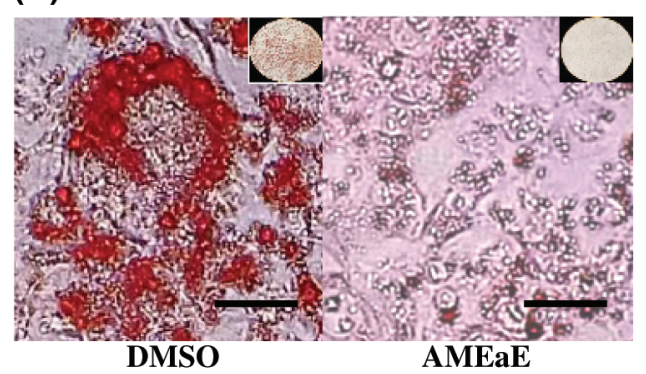

FIGURE 3. Annona montana ethyl acetate extract decreased the number and the size of lipid droplets during adipogenesis. Preadipocytes were incubated with induction medium in the presence of DMSO-control or containing $10 \mu \mathrm{g} / \mathrm{mL}$ A. montana ethyl acetate extract (AMEaE) for nine days. After differentiation, the cells were stained with Oil Red $\mathrm{O}$ and then photographed. (A) The total number of lipid droplets was quantified from at least 100 cells. ${ }^{\star} P<0.05$ DMSO-control vs. AMEaE-treatment. (B) The perimeters of 1584 lipid droplets from forty-eight control cells and 1092 lipid droplets from fifty-two of AMEaE-treated cells were obtained with the use of NIH Image software. Lipid droplets have a diameter in the range of 0.81 to $3.90 \mu \mathrm{m} .{ }^{\star} P<0.05$ DMSOcontrol vs. AMEaE-treatment. Results were represented as percentage of DMSO-control. (C) 3T3-L1 preadipocytes were monitored under a microscope and photographed after nine days from the onset of differentiation. Cells treated with induction media in the presence of DMSO-control, or in the presence of 10 $\mu \mathrm{g} / \mathrm{mL}$ AMEaE. Scale bars: $10 \mu \mathrm{m}$. Insets show the field of vision.

differentiation of mouse 3T3-L1 and human preadipocytes by affecting the expression of one or more transcriptional factors (i.e., inhibition expression of PPAR $\gamma$ ), which would be consistent with the robust effect of $A$. montana ethyl acetate extract on the number and size of the lipid droplets.

Annona montana ethyl acetate extract inhibits key adipogenic transcriptional factors

A coordinated network of expression and activation of key transcriptional factors and signaling molecules is critical for adipogenesis (Rosen and Spiegelman, 2000). PPAR $\gamma$ and $\mathrm{C}-\mathrm{EBPa}$ are two major adipogenic transcription factors, which are required during the early steps of preadipocytes differentiation (Rosen et al., 2002). To investigate whether $A$. montana ethyl acetate extract affects the expression of PPAR $\gamma$ and C-EBPa, we incubated 3T3-L1 preadipocytes with induction media in the absence or presence of $10 \mu \mathrm{g} / \mathrm{mL}$ A. montana ethyl acetate extract. We then harvested the cells at day 9 for western blotting analysis using anti-PPAR $\gamma$ and anti-C/EBPa antibodies, respectively.

In Figs. 5A and 5B, we showed that the addition of $A$. montana ethyl acetate extract attenuated the expression of PPAR $\gamma$ and $\mathrm{C} / \mathrm{EBP} \alpha$ as well as other adipogenic factors (e.g., FAS, Fig. 5C). We also examined whether the addition of $A$. montana ethyl acetate extract affected the phosphorylation of AMPKa during 3T3-L1 preadipocyte differentiation. This result shows that phosphorylation of AMPKa (p-AMPKa) was not inhibited by the addition of $A$. montana ethyl acetate extract.

In contrast, $A$. montana ethyl acetate extract enhanced phosphorylation of AMPKa (Fig. 5D). In addition, we also found that the level of total expression of AMPKa was not affected in the presence or absence of A. montana ethyl acetate extract. Therefore, these results indicated that the level of phosphorylated AMPKa increased in the presence of A. montana ethyl acetate extract. However, the expression of PPAR $\gamma$ was inhibited by more than $95 \%$ upon the addition of $A$. montana ethyl acetate extract.

We also examined the effect of $A$. montana ethyl acetate extract on the phosphorylation of Akt1 and Erk1/2 proteins. Surprisingly, we found that the addition of A. montana ethyl acetate extract attenuated phosphorylation of Akt1 (Fig. 5E), without inhibiting the phosphorylation of Erk1/2 (data not shown). Interestingly, the total level of expression of AkT-1 and AMPKa were not affected by the addition of A. montana ethyl acetate extract (Figs. 5D and 5E), We also tested whether the addition of $A$. montana ethyl acetate extract affected the expression of HMGB2 factor, an early stage adipogenic factor (Lee et al., 2018), during 3T3-L1 preadipocyte differentiation. The result indicated that the addition of this extract also inhibited the expression of HMGB2 (Fig. 5F). Altogether, these data suggest that the $A$. montana ethyl acetate extract strongly and selectively blocks the expression of PPAR $\gamma$ and HMGB2, and also decreases the expression of FAS and Aktl during the differentiation of 3T3-L1 preadipocytes, which indicates that A. montana ethyl acetate extract may affect early adipocyte gene expression during in vitro differentiation.

\section{Chemical Composition of the Annona montana ethyl acetate} extract

Chemical studies with species of the Annona genus have reported on the essential oils found in the fruits, whose composition is predominantly of monoterpenes and sesquiterpenes and alkaloids. Because many Annonaceae fruits are edible, they are the predominant focus of many studies. On the contrary, few studies have been performed on the leaves. Thus, we conducted a Gas ChromatographyMass Spectrometry (GC-MS) analysis as described in Material and Methods to gain more information about the composition of the constituents, specifically in the $A$. montana ethyl acetate extract. Our results on $A$. montana ethyl acetate leaves extract indicated that twenty-two compounds out of a total of twenty-seven compounds were identified, (Table 1 and Supplemental Table 1) in a complex mixture of sesquiterpenes (i.e., $\alpha$-copaene, $\beta$-elemene, $\beta$ caryophyllene and $\delta$-cadinene), fatty acids (i.e., Linoleic 
(A)

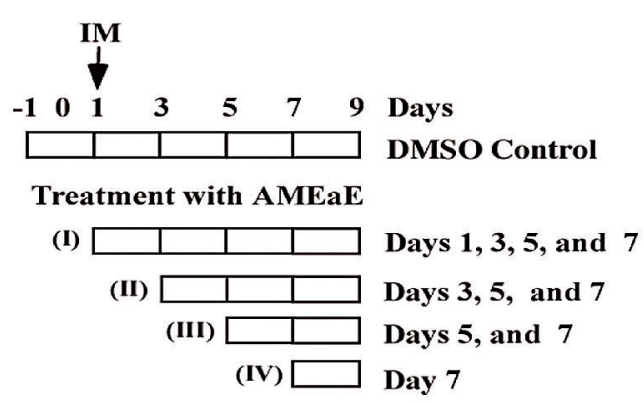

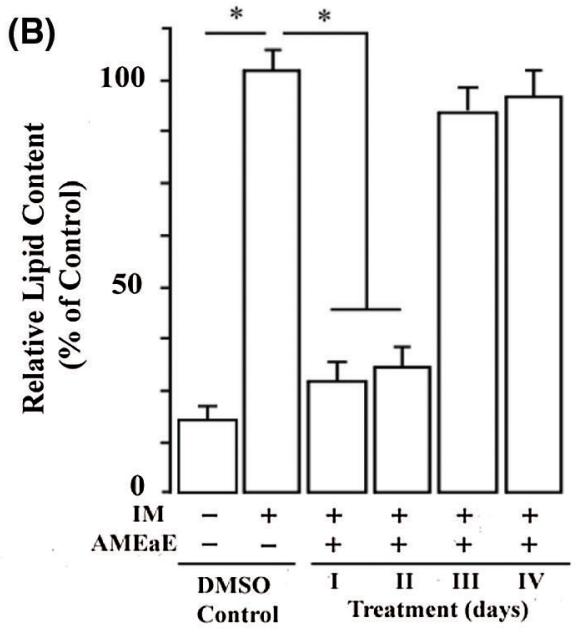

(C)

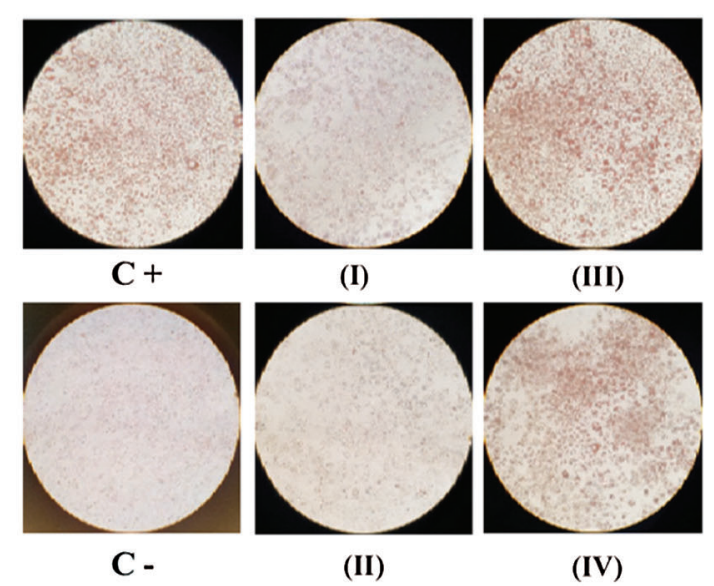

FIGURE 4. Annona montana ethyl acetate extract blocked adipocyte differentiation in a time-dependent manner.

(A) 3T3-L1 preadipocyte cells incubated with induction medium alone (IM) in the presence of DMSO-control or treated with $10 \mu \mathrm{g} / \mathrm{mL} A$. montana ethyl acetate extract (AMEaE) for the time indicated in the schematic representation of the experiment. (B) In each treatment (i.e., I, II, III and IV), the accumulation of lipid droplets was measured by the incorporation of Oil Red O as described in Material and Methods. Data represent the mean \pm S.E.M. of three independent experiments. ${ }^{\star} P<0.05$ by two Student's $t$-test compared to DMSO-control induction mediatreated cells (control, C+). Vehicle only (C-) was also shown. (C) 3T3-L1 preadipocytes were monitored under a microscope and photographed after nine days (Day 9) from the onset of differentiation (Day 0). Cells treated in the absence (control, C-) or in the presence of induction media with DMSO (Control, C+), or with $10 \mu \mathrm{g} / \mathrm{mL}$ AMEaE for each specific treatment (I to IV) as indicated in the figure.

acid, Octadecanoic acid), phytosterols (i.e., Campesterol, $\gamma$-Sitosterol and Stigmasta-5,22-dien-3-ol), hydrocarbons (i.e., 1-Hexacosanol, 9-Hexacosene and 1-Docosanethiol), $\beta$-tocopherol, 1,22-Docosanediol, and Z-11(13-Methyl) tetradecen-1-ol acetate. Interestingly, some of these compounds have been reported to affect some cellular mechanisms of cell proliferation and apoptosis in cancer cells as well as they may reduce hyperglycemia in Streptozotocininduced diabetic rats (Balamurugan et al., 2011; Sundarraj et al., 2012).

\section{Discussion}

Several studies have determined that the utilization of both leaves and fruits of medicinal plants can lessen the occurrence of risk factors involved in obesity and cancer (Agostini et al., 1995; Coria-Téllez et al., 2018; Matsuda et al., 2014; Meneguetti et al., 2011). Our results demonstrate that A. montana's leaves extracts studied in this research may be beneficial for the control and prevention of fat formation and its risk factors, since the extracts reduced lipid droplet formation in adipocytes by affecting several adipogenic factors.

Two major adipogenic transcription factors, PPAR $\gamma$ and $\mathrm{C}$-EBPa, work together to induce the expression of adipocytespecific genes, which are involved in the switch between proliferation and differentiation in cells (Rosen et al., 2002). Studies on adipogenic cell lines have also shown that HMGB2 is expressed during adipogenesis and seems to be upstream of PPAR $\gamma$ and C-EBPa (Lee et al., 2018). The activity of the critical enzyme fatty acid synthetase facilitates the formation of cytoplasmic triglyceride, the end-product of the lipogenic pathway during the differentiation of 3T3-L1 cells (Student et al., 1980). Furthermore, both PI3K/Akt and Ras/Erk signaling pathways are critical and may affect adipogenesis in distinct ways depending on their appropriate time of activation upon insulin stimulation during the differentiation process (Kim and Chen, 2004; Prusty et al., 2002).

Our in vitro data showed that PPAR $\gamma$ and HMGB2 were among the genes that were strongly downregulated by the addition of $A$. montana ethyl acetate extract. The extract also inhibited the expression of $\mathrm{C}-\mathrm{EBPa}$ and Akt but to a 
(A)

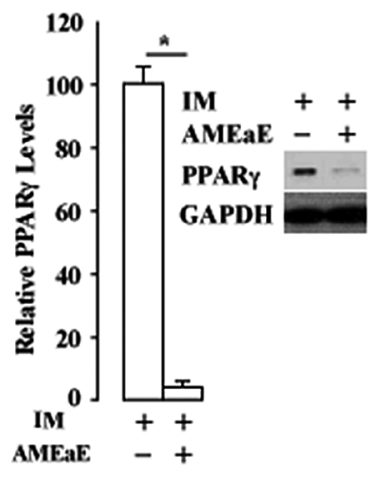

(B)

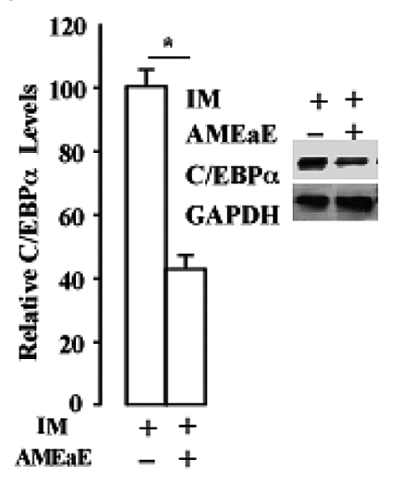

(C)

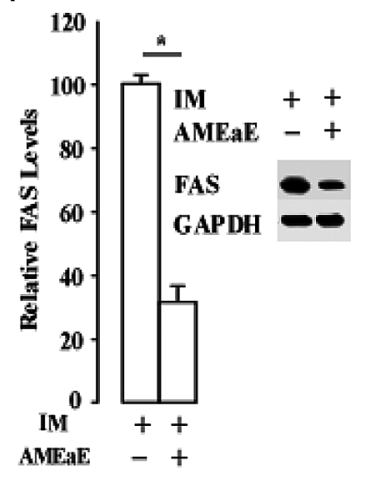

(D)

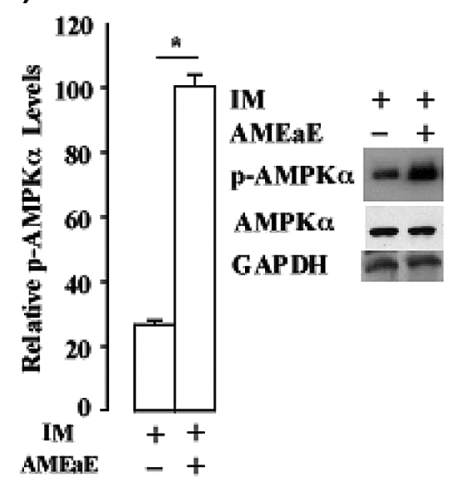

(E)

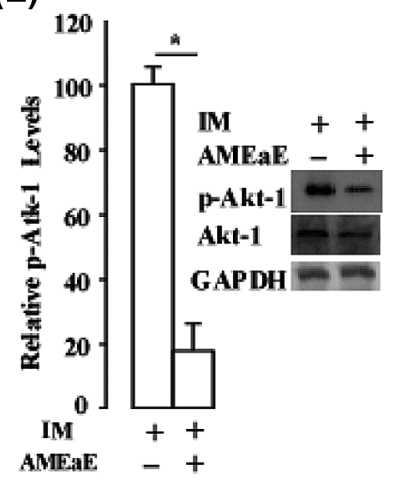

(F)

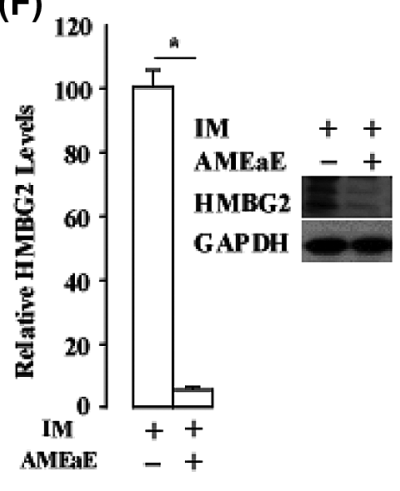

FIGURE 5. Annona montana ethyl acetate extract strongly attenuated the expression of PPAR $\gamma$ during 3T3-L1 preadipocyte differentiation. 3T3-L1 preadipocyte differentiation was induced by induction media (IM) alone in the presence of DMSO-control, or in the absence or the presence of $10 \mu \mathrm{g} / \mathrm{mL}$ A. montana ethyl acetate extract (AMEaE) (inset: -AMEaE, +AMEaE). Total protein extracts were prepared on Day 9 from each sample, and probed with antibodies specific to (A-B) PPAR $\gamma$, C-EBPa and GAPDH, (C) FAS and GAPDH, (D) p-AMPKa, t-AMPKa, (E) p-Akt1, t-Akt1 and (F) HMGB2, respectively. GAPDH was used as loading control. Relative levels of proteins were determined by densitometry as described in Material and Methods. Data represent the mean \pm S.E.M. of three independent experiments. ${ }^{\star} P<0.05$ by two student's $t$-tests compared to DMSO IM-treated cells.

lesser extent. In contrast, Erk activity was not affected in the presence of A. montana ethyl acetate extract even at higher concentrations (data not show). Treatment of 3T3-L1 preadipocytes with $A$. montana ethyl acetate extract dramatically reduced protein expression of PPAR $\gamma$, which is strictly concordant with the appearance of cytoplasmic lipid droplets. These data suggest that this extract may target specific pathways related to the expression of PPAR $\gamma$ and, in lesser extension, the expression $\mathrm{C}-\mathrm{EBP} \alpha$, due to the extract's strong inhibition of PPAR $\gamma$. Furthermore, our observations showed that the A. montana ethyl acetate extract might have selective effects on adipocyte differentiation since Akt activity, which are thought to be sensitive to insulin stimulation, were also affected by the addition of $A$. montana ethyl acetate extract. Consistent with this result, Akt has been demonstrated to regulate adipogenesis via phosphorylation by inactivating Foxol, in which Foxol is known to regulate PPAR $\gamma$ activity directly (Nakae et al., 2003). Thus, it is reasonable to consider that A. montana ethyl acetate extract may selectively block pathways specific to these two signaling molecules (i.e., AKT and PPAR $\gamma$ ) by regulating adipocytic differentiation containing the adipocyte-specific factor.

The effects of other Annona's species on several biological assays have also been evaluated. Aqueous and methanol extracts from $A$. muricata leaves showed both hypoglycemic and antioxidant effects on diabetic and on Streptozotocininduced diabetic rats (Adeyemi et al., 2008). Remarkably, even though $A$. muricata, A. squamosa, and A. reticulata presented antioxidant activities, it was concluded that $A$. muricata had more potent antioxidant activities in several in vitro studies (Baskar et al., 2007). Studies have also shown that the administration of extracts prepared from $A$. squamosa produced an inhibitory effect on glycemic and lipemic indices as well as on the levels of the antioxidant enzymes (i.e., glutathione reductase) (Gupta et al., 2005; Kaleem et al., 2006). However, studies on A. crassiflora have shown minimal effects on lipemia and glycemia in rats (Dragano et al., 2010). Ethanolic extracts from A. cuneate, $A$. coriaceae, and $A$. senegalensis showed a strong antiinflammatory effect, which is likely due to the high content in the variety of polyphenolic components and vitamins (i.e., Vitamin C). These effects may be attributed to the presence of compounds such as polyphenols, flavonoids, steroids, and a series of secondary metabolites that can contribute to the reduction of glycemia and antiinflammatory effects (Barbalho et al., 2011; Coria-Téllez et al., 2018; Dragano et al., 2010; Grover et al., 2011), which could increase the range of therapeutic effects of this species.

Our results indicated the presence of alkaloids, acetogenins, phenols, carotenoids, amides, cylopeptides, sesquiterpenes, and aromatic and aliphatic esters in the 
TABLE 1

Chemical composition and percentage of compounds from the leaves of Annona montana ethyl acetate extract

\begin{tabular}{|c|c|c|c|}
\hline & & $\mathrm{Rt} / \mathrm{min}$ & Area \\
\hline 1 & a-Copaene & 15.03 & 0.9 \\
\hline 2 & $\beta$-Elemene & 15.42 & 0.7 \\
\hline 3 & $\beta$-Caryophyllene & 16.15 & 0.4 \\
\hline 4 & $\delta$-Cadinene & 17.65 & 2.1 \\
\hline 5 & Unknown & 24.82 & 0.5 \\
\hline 6 & cis-pinane & 25.46 & 4.7 \\
\hline 7 & Unknown & 25.59 & 4.3 \\
\hline 8 & 1,4-Eicosadiene & 26.32 & 1.3 \\
\hline 9 & n-Hexadecanoic acid & 27.91 & 6.6 \\
\hline 10 & Phytol & 30.70 & 1.8 \\
\hline 11 & Linoleic acid & 31.06 & 7.2 \\
\hline 12 & Octadecanoic acid & 31.56 & 1.5 \\
\hline 13 & 1-Docosanethiol & 37.00 & 3.5 \\
\hline 14 & Octadecanal & 37.60 & 1.0 \\
\hline 15 & Docosanoic Acid & 38.12 & 0.9 \\
\hline 16 & 1,22-Docosanediol & 39.13 & 0.6 \\
\hline 17 & 1-Hexacosene & 42.86 & 3.6 \\
\hline 18 & Unknown & 43.15 & 1.4 \\
\hline 19 & Z-11(13-Methyl)tetradecen-1-ol acetate & 44.73 & 1.2 \\
\hline 20 & $\beta$-tocopherol & 44.95 & 2.3 \\
\hline 21 & Unknown & 45.12 & 19.0 \\
\hline 22 & 1-Hexacosanol & 45.53 & 7.4 \\
\hline 23 & Campesterol & 47.20 & 3.1 \\
\hline 24 & Unknown & 47.26 & 2.0 \\
\hline 25 & Stigmasta-5,22-dien-3-ol & 47.6 & 2.8 \\
\hline 26 & 9-Hexacosene & 48 & 2.8 \\
\hline \multirow[t]{2}{*}{27} & $\gamma$-Sitosterol & 48.32 & 11 \\
\hline & Total & & 94.6 \\
\hline
\end{tabular}

Note: RT: Retention time. The compounds were identified using the National Institute of Standards and Technology (NIST) EPA NIH mass spectral database program (NIST v17; version 2.3).

A. montana ethyl acetate extract. Some of these compounds have also been identified in A. muricata extracts (CoriaTéllez et al., 2018). Additionally, we have described the presence of several sesquiterpenes (i.e., $\alpha$-Copaene, $\beta$ Caryophyllene, $\beta$-Elemane, and $\delta$-Cadinene) in the ethyl acetate fraction. Interestingly, some of these terpenes have been implicated in the inhibition of proliferation of several types of cancer cells and in PARP expression (Hui et al., 2015; Matsuda et al., 2014), which can help us to explain, at least in part, the inhibitory effect of $A$. montana extracts.

\section{Conclusion}

These results demonstrate that $A$. montana leaves extracts strongly inhibited in vitro differentiation of mouse and human preadipocytes, which may indicate useful applications to human health by helping to lower the incidence of chronic degenerative diseases. Future investigations on plant extracts' effects on adipogenesis would also expand from the inclusion of other species of the genus (e.g., A. muricata, A. crassiflora, A. diversifolia, and A. squamosa).

Acknowledgement: The authors are grateful to Dr. Barbieri laboratory's members for their insightful comments.

Author Contribution: The authors confirm contribution to the paper as follows: study conception and design: I. Leung, M. A. Barbieri; data collection: I. Leung, W. Zhang, M. Espinal; analysis and interpretation of results: I. Leung, M. A. Barbieri; draft manuscript preparation: M. L. Veisaga, M. A. Barbieri. All authors reviewed the results and approved the final version of the manuscript.

Availability of Data and Materials: All data generated or analyzed during this study are included in this published article.

Funding Statement: This work was partially supported by the National Institutes of Health Grant SC1DK084343, and 
by the U. S. Department of Defense Grant W911NF-13-0167 (to $\mathrm{MAB}$ ).

Conflicts of Interest: The authors declare that they have no conflicts of interest to report regarding the present study.

\section{References}

Abood S, Veisaga ML, López LA, Barbieri MA (2018). Dehydroleucodine inhibits mitotic clonal expansion during adipogenesis through cell cycle arrest. Phytotherapy Research 32: 1583-1592.

Abrams DI, Couey P, Shade SB, Kelly ME, Kamanu-Elias N, Stamets P (2011). Antihyperlipidemic effects of Pleurotus ostreatus (oyster mushrooms) in HIV-infected individuals taking antiretroviral therapy. BMC Complementary and Alternative Medicine 11: 60.

Adams RP (2007). Identification of Essential Oil Components by Gas Chromatography/Quadrupole Mass Spectroscopy. 4th edition. Carol Stream, IL: Allured Publ.

Adewole SO, Ojewole JA (2008). Protective effects of Annona muricata Linn. (Annonaceae) leaf aqueous extract on serum lipid profiles and oxidative stress in hepatocytes of streptozotocin-treated diabetic rats. African Journal of Traditional Complementary Alternative Medicine 6: 30-41.

Adeyemi DO, Komolafe OA, Adewole OS, Obuotor EM, Adenowo TK (2008). Anti hyperglycemic activities of Annona muricata (Linn). African Journal of Traditional Complementary Alternative Medicine 6: 62-69.

Agostini Tda S, Cecchi HM, Barrera-Arellano D (1995). Chemical characteristics of the pulp and oil of the annona tree (Annona coriaceae). Archivos Latinoamericanos de Nutricion 45: 237-241.

Araujo HC, Lacerda ME, Lopes D, Bizzo HR, Kaplan MA (2007). Studies on the aroma of mate (Ilex paraguariensis St. Hil.) using headspace solid-phase microextraction. Phytochemical Analysis 18: 469-474. DOI 10.1002/(ISSN)1099-1565.

Babushok VI, Linstrom PJ, Zenkevich IG (2011). Retention indices for frequently reported compounds of plant essential oils. Journal of Physical and Chemical Reference Data 40: 043101. DOI 10.1063/1.3653552.

Bailon-Moscosoa N, Romero Benavides JC, Ramirez Orellana MI, Ojeda K, Granda G et al. (2016). Cytotoxic and genotoxic effects of extracts from Annona montana M. fruit. Food and Agricultural Immunology 7: 559-569.

Beck B, Chen YF, Dere W, Devanarayan V, Eastwood BJ, Farmen MW, Iturria SJ, Iversen PW, Kahl SD, Moore RA, Sawyer BD, Weidner J (2012). Assay operations for SAR support. In: Markossian S (Ed.), Assay Guidance Manual. Eli Lilly \& Company and the National Center for Advancing Translational Sciences.

Balamurugan R, Duraipandiyan V, Ignacimuthu S (2011). Antidiabetic activity of $\gamma$-sitosterol isolated from Lippia nodiflora L. in streptozotocin induced diabetic rats. European Journal of Pharmacology 667: 410-418. DOI 10.1016/j.ejphar.2011.05.025.

Barbalho SM, Damasceno DC, Spada AP, Lima IE, Araujo AC et al. (2011). Effects of Passiflora edulis on the metabolic profile of diabetic Wistar rat offspring. Journal of Medicinal Food 14: 1490-1495. DOI 10.1089/jmf.2010.0318.

Baskar R, Rajeswari V, Kumar TS (2007). In vitro antioxidant studies in leaves of Annona species. Indian Journal of Experimental Biology 45: 480-485.
Bost F, Aouadi M, Caron L, Binetruy B (2005). The role of MAPKs in adipocyte differentiation and obesity. Biochimie 87: 51-56. DOI 10.1016/j.biochi.2004.10.018.

Carballo AI, Martinez AL, Gonzalez-Trujano ME, Pellicer F, Ventura-Martinez R et al. (2010). Antinociceptive activity of Annona diversifolia Saff. leaf extracts and palmitone as a bioactive compound. Pharmacology Biochemistry and Behavior 95: 6-12. DOI 10.1016/j.pbb.2009.11.017.

Chatrou LW, Pire MD, Erkens RHJ, Couvreur TLP, Nuebig KM et al. (2012). A new subfamilial and tribal classification of the pantropical flowering plant family Annonaceae informed by molecular phylogenetics. Botanical Journal of the Linnean Society 169: 5-40. DOI 10.1111/j.10958339.2012.01235.x.

Collaborators GBDO, Afshin A, Forouzanfar MH, Reitsma MB, Sur P et al. (2017). Health effects of overweight and obesity in 195 countries over 25 years. New England Journal of Medicine 377: 13-27. DOI 10.1056/NEJMoa1614362.

Coria-Téllez AV, Montalvo-Gónzalez E, Yahia EM, Obledo-Vázquez EN (2018). Annona muricata: A comprehensive review on its traditional medicinal uses, phytochemicals, pharmacological activities, mechanisms of action and toxicity. Arabian Journal of Chemistry 11: 662-691. DOI 10.1016/j.arabjc.2016.01.004.

de Souza Mda S, Barbalho SM, Damasceno DC, Rudge MV, de Campos KE et al. (2012). Effects of Passiflora edulis (yellow passion) on serum lipids and oxidative stress status of Wistar rats. Journal of Medicinal Food 15: 78-82. DOI 10.1089/jmf.2011.0056.

Degli Esposti M, Ghelli A, Ratta M, Cortes D, Estornell E (1994). Natural substances (acetogenins) from the family Annonaceae are powerful inhibitors of mitochondrial NADH dehydrogenase (Complex I). Biochemical Journal 301: 161-167. DOI 10.1042/ bj3010161.

Dragano NR, de Venancio VP, Paula FB, Della Lucia F, Fonseca MJ et al. (2010). Influence of Marolo (Annona crassiflora Mart.) pulp intake on the modulation of mutagenic/antimutagenic processes and its action on oxidative stress in vivo. Plant Foods for Human Nutrition 65: 319-325. DOI 10.1007/ s11130-010-0191-3.

Galvis A, Marcano A, Stefancin C, Villaverde N, Priestap HA et al. (2011). The effect of dehydroleucodine in adipocyte differentiation. European Journal of Pharmacology 671: 1825. DOI 10.1016/j.ejphar.2011.09.033.

Grover GJ, Koetzner L, Wicks J, Gahler RJ, Lyon MR, Reimer RA, Wood S (2011). Effects of the soluble fiber complex polyGlycopleX? on glucose homeostasis and body weight in young zucker diabetic rats. Frontiers in Pharmacology 2: 47. DOI 10.3389/fphar.2011.00047.

Gupta RK, Kesari AN, Murthy PS, Chandra R, Tandon V et al. (2005). Hypoglycemic and antidiabetic effect of ethanolic extract of leaves of Annona squamosa L. in experimental animals. Journal of Ethnopharmacology 99: 75-81. DOI 10.1016/j.jep.2005.01.048.

Hui LM, Zhao GD, Zhao JJ (2015). Delta-Cadinene inhibits the growth of ovarian cancer cells via caspase-dependent apoptosis and cell cycle arrest. International Journal of Clinical Experiemntal Pathology 8: 6046-6056.

Kaleem M, Asif M, Ahmed QU, Bano B (2006). Antidiabetic and antioxidant activity of Annona squamosa extract in streptozotocin-induced diabetic rats. Singapore Medical Journal 47: 670-675.

Kemp BE, Stapleton D, Campbell DJ, Chen ZP, Murthy S et al. (2003). AMP-activated protein kinase, super metabolic 
regulator. Biochemical Society Transactions 31: 162-168. DOI 10.1042/bst0310162.

Kim JE, Chen J (2004). Regulation of peroxisome proliferatoractivated receptor-gamma activity by mammalian target of rapamycin and amino acids in adipogenesis. Diabetes 53: 2748-2756. DOI 10.2337/diabetes.53.11.2748.

Lee D, Taniguchi N, Sato K, Choijookhuu N, Hishikawa Y et al. (2018). HMGB2 is a novel adipogenic factor that regulates ectopic fat infiltration in skeletal muscles. Scientific Reports 8: 219. DOI 10.1038/s41598018-28023-7.

Matsuda H, Nakamura S, Yoshikawa M (2014). Search for new type of PPARgamma agonist-like anti-diabetic compounds from medicinal plants. Biological and Pharmaceutical Bulletin 37: 884-891. DOI 10.1248/bpb.b14-00037.

Meneguetti QA, Brenzan MA, Batista MR, Bazotte RB, Silva DR, Garcia Cortez DA (2011). Biological effects of hydrolyzed quinoa extract from seeds of Chenopodium quinoa Wild. Journal of Medicinal Food 14: 653-657. DOI 10.1089/ jmf.2010.0096.

Moghadamtousi SZ, Fadaeinasab M, Nikzad S, Mohan G, Ali HM, Kadir HA (2015). Annona muricata (Annonaceae): A review of its traditional uses, isolated acetogenins and biological activities. International Journal of Molecualr Sciences 16: 15625-15658. DOI 10.3390/ijms160715625.

Mootoo BS, Ali A, Khan A, Reynolds WF, McLean S (2000). Three novel monotetrahydrofuran annonaceous acetogenins from Annona montana. Journal of Natural Products 63: 807-811. DOI 10.1021/np9903301.

Nakae J, Kitamura T, Kitamura Y, Biggs WH III, Arden KC et al. (2003). The forkhead transcription factor Foxol regulates adipocyte differentiation. Developmental Cell 4: 119-129. DOI 10.1016/S1534-5807(02)00401-X.

Parraga I, Lopez-Torres J, Andres F, Navarro B, del Campo JM et al. (2011). Effect of plant sterols on the lipid profile of patients with hypercholesterolaemia. Randomised, experimental study. BMC Complementary and Alternative Medicine 11: 172. DOI 10.1186/1472-6882-11-73.

Ponrasu T, Suguna L (2012). Efficacy of Annona squamosa on wound healing in streptozotocin-induced diabetic rats. International Wound Journal 9: 613-623. DOI 10.1111/ j.1742-481X.2011.00924.x.

Prusty D, Park BH, Davis KE, Farmer SR (2002). Activation of MEK/ERK signaling promotes adipogenesis by enhancing peroxisome proliferator-activated receptor $\gamma(\operatorname{PPAR} \gamma)$ and $\mathrm{C} / \mathrm{EBPa}$ gene expression during the differentiation of
3T3-L1 preadipocytes. Journal of Biological Chemistry 277: 46226-46232. DOI 10.1074/jbc.M207776200.

Rauter AP, Palma FB, Justino J, Araújo ME, dos Santos SP (2002). Toxicity of some species of annona toward artemia salina leach and biomphalaria glabrata Say. Natural Products in the New Millennium: Prospects and Industrial Application 47: 263-270.

Roberts DL, Dive C, Renehan AG (2010). Biological mechanisms linking obesity and cancer risk: New perspectives. Annual Review of Medicine 61: 301-316. DOI 10.1146/annurev. med.080708.082713.

Rosen ED, Hsu CH, Wang X, Sakai S, Freeman MW et al. (2002). C/EBPalpha induces adipogenesis through PPARgamma: A unified pathway. Genes \& Development 16: 22-26. DOI 10.1101/gad.948702.

Rosen ED, Spiegelman BM (2000). Molecular regulation of adipogenesis. Annual Review of Cell and Developmetal Biology 16: 145-171. DOI 10.1146/annurev.cellbio.16.1.145.

Spiegelman BM, Choy L, Hotamisligil GS, Graves RA, Tontonoz P (1993). Regulation of adipocyte gene expression in differentiation and syndromes of obesity/diabetes. Journal of Biological Chemistry 268: 6823-6826. DOI 10.1016/ S0021-9258(18)53107-0.

Student AK, Hsu RY, Lane MD (1980). Induction of fatty acid synthetase synthesis in differentiating 3T3-L1 preadipocytes. Journal of Biological Chemistry 255: 4745-4750. DOI 10.1016/S0021-9258(19)85559-X.

Sundarraj S, Thangam R, Sreevani V, Kaveri K, Gunasekaran P, Achiraman S, Kannan S (2012). Gamma-Sitosterol from Acacia nilotica L. induces $\mathrm{G} 2 / \mathrm{M}$ cell cycle arrest and apoptosis through c-Myc suppression in MCF-7 and A549 cells. Journal of Ethnopharmacology 141: 803-809. DOI 10.1016/j.jep.2012.03.014.

Taleghani A, Emami SA, Tayarani-Najaran Z (2020). Artemisia: A promising plant for the treatment of cancer. Bioorganic \& Medicinal Chemistry 28: 115180. DOI 10.1016/j.bmc.2019.115180.

Tundis R, Xiao J, Loizzo MR (2017). Annona species (Annonaceae): A rich source of potential antitumor agents? Annals of the New York Academy of Sciences 1398: 30-36.

Wang LQ, Min BS, Li Y, Nakamura N, Qin GW et al. (2002). Annonaceous acetogenins from the Leaves of Annona montana. Bioorganic \& Medicinal Chemistry 10: 561-565. DOI 10.1016/S0968-0896(01)00303-0.

Wu YC, Chang GY, Ko FN, Teng CM (1995). Bioactive constitutents from the stems of Annona montana. Planta Medica 61: 146149. DOI 10.1055/s-2006-958035. 
SUPPLEMENTAL TABLE 1

Chemical composition and percentage of compounds from the leaves of Annona montana ethyl acetate extraction

\begin{tabular}{lllll}
\hline Component & $\mathbf{\%}$ & $\mathbf{R i}^{\mathbf{a}}$ & $\mathbf{R i}^{\mathbf{b}}$ & Identification $^{\mathbf{c}}$ \\
\hline a-Copaene & 1.1 & 1375 & 1368 & $1,2,3$ \\
$\delta$-Elemene & 0.9 & 1338 & 1327 & $1,2,3$ \\
$\beta$-Caryophyllene & 0.4 & 1588 & 1598 & $1,2,3$ \\
$\delta$-Cadinene & 2.1 & 1755 & 1722 & $1,2,3$ \\
cis-Pinane & 5.1 & 1002 & 1018 & 1,2 \\
1,4-Eicosadiene & 1.1 & 2007 & 1997 & 1,2 \\
n-Hexadecanoic acid & 7.6 & 2913 & 2862 & 1,2 \\
Phytol & 2.1 & 2613 & 2619 & 1,2 \\
Linoleic acid & 2.1 & 3148 & 3201 & $1,2,3$ \\
Octadecanoic acid & 1.7 & 2158 & 2142 & 1,2 \\
1-Docosanethiol & 4.1 & 1518 & 1536 & 1,2 \\
Octadecane & 1.1 & 1357 & 1387 & 1,2 \\
Docosanoic Acid & 0.7 & 2560 & 2490 & 1,2 \\
1,22-Docosanediol & 0.4 & 1518 & 1536 & 1,2 \\
1-Hexacosene & 4.1 & 2593 & 2578 & 1,2 \\
Z-11(13-Methyl)tetradecen-1-ol acetate & 1.1 & 1822 & 1875 & 1,2 \\
$\beta$-tocoperol & 40.1 & 3075 & 3068 & $1,2,3$ \\
1-Hexacosanol & 3.2 & 2932 & 2905 & 1,2 \\
Campesterol & 3.1 & 3305 & 3354 & $1,2,3$ \\
Stigmasta-5,22-dien-3-ol & 3.3 & 2739 & 2810 & 1,2 \\
$\gamma$-Sitosterol & 12.1 & 3790 & 3798 & $1,2,3$ \\
\hline No: Ra & & $\mathbf{c} 2,3$
\end{tabular}

Note: $\mathrm{RI}^{\mathrm{a}}$ : retention indices $\left(\mathrm{DB}-5\right.$ column) calibrated against $\mathrm{n}$-alkanes; $\mathrm{RI}^{\mathrm{b}}$ : reference retention indices recorded in the literature [Adams, 2007; Babushok et al., 2011; Araujo et al.,

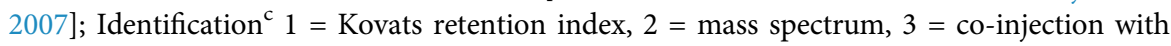
authentic compound.

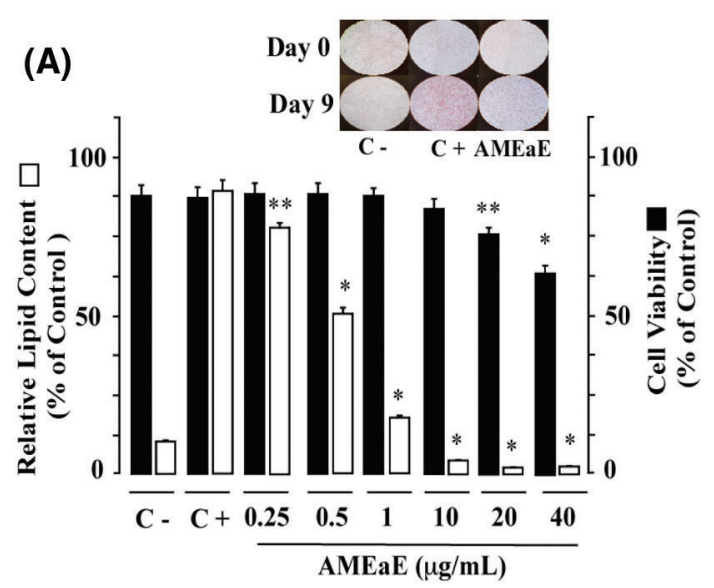

(B)
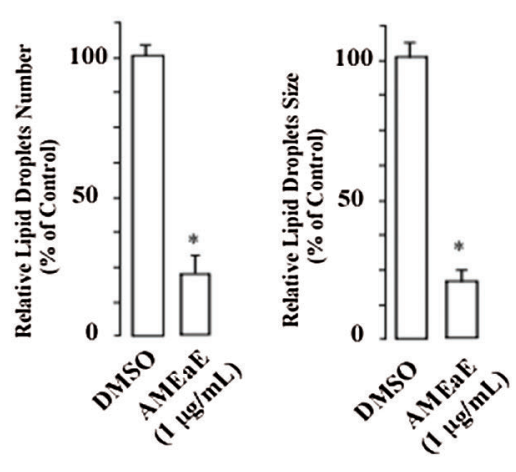

SUPPLEMENTAL FIGURE 1. Annona montana methanol extract inhibited adipogenesis of human preadipocytes. (A) Human preadipocytes were differentiated into adipocytes with induction media in the absence or the presence of various amounts of $A$. montana methanol extract ( 0 to $40 \mu \mathrm{g} / \mathrm{mL}$ ) as described in Material and Methods. Vehicle only (C-), cells treated with induction media in the presence of DMSO-control $(\mathrm{C}+)$, or in the presence of different concentration of A. montana methanol extract (AMEaE). Results were represented as relative lipid contents for adipocyte formation (open bars) and as percentage of control for cell viability (solid bars). Data represent the mean \pm S.E.M. of three independent experiments. ${ }^{\star} P<0.05$ and ${ }^{* *} P<0.01$ by one-way ANOVA test compared to DMSO-control and only induction media-treated cells $(0 \mu \mathrm{g} / \mathrm{mL})$. Insets show the field of vision. (B) Human preadipocytes were incubated with induction medium in the presence of DMSO-control or containing $1 \mu \mathrm{g} / \mathrm{mL}$ A. montana ethyl acetate extract (AMEaE) for nine days. After differentiation, the cells were stained with Oil Red $\mathrm{O}$ and then photographed and the total number (left) of lipid droplets was quantified from at least 100 cells. ${ }^{\star} P<0.05$ DMSO-control vs. AMEaE-treatment. The perimeters (right) of 1354 lipid droplets from forty-eight control cells and 990 lipid droplets from fifty-two of AMEaE-treated cells were obtained with the use of NIH Image software. Lipid droplets have a diameter in the range of 0.61 to $2.90 \mu \mathrm{m} .{ }^{\star} P<0.05 \mathrm{DMSO}$-control $v$ s. AMEaE-treatment. Results were represented as percentage of DMSO-control. 